\title{
Potentials of Bamboo-Based Agroforestry for Sustainable Development in Sub-Saharan Africa: A Review
}

\author{
Samuel T. Partey ${ }^{1,2} \cdot$ Daniel A. Sarfo ${ }^{1} \cdot$ Oliver Frith $^{1} \cdot$ Michael Kwaku $^{1} \cdot$ Naresh V. $_{\text {Thevathasan }}^{3}$
}

Received: 1 June 2016/Accepted: 6 January 2017/Published online: 19 January 2017

(C) NAAS (National Academy of Agricultural Sciences) 2017

\begin{abstract}
There is widespread assertion among scientists, government and development experts that bamboo agroforestry could contribute to sustainable rural development in Sub-Saharan Africa (SSA). However, there are limited available data to verify the suitability of the system in the region. In addition, the current state of knowledge and adoption of agroforestry in SSA offers very little guidance as to which type of agroforestry systems bamboo could be integrated. Here, we reviewed the potential socioeconomic and environmental benefits of bamboo agroforestry and accentuate implications on sustainable rural development in SSA. In addition, we analysed potential research areas that could be intensified, so that future developments and scaling-up of bamboo agroforestry can be rooted in robust scientific findings rather than the intuitions of governments and development actors.
\end{abstract}

Keywords Agroforestry · Deforestation - Land-use systems $\cdot$ Ecosystem services $\cdot$ Bamboo $\cdot$ Sustainability $\cdot$ Africa

\section{Introduction}

Agriculture is the mainstay of most national economies of Sub-Saharan Africa (SSA), and its development has significant implications on food security and poverty reduction as highlighted in the United Nation's Sustainable Development Goals (SDGs). One focus of the SDGs is enhancing global agriculture to meet the food security needs of ever increasing population [13]. This is particularly critical in developing countries where food production is not keeping pace with increasing population [46, 50]. Although an economic booster, improvements in SSA's agriculture sector are increasingly hampered by land tenure

Samuel T. Partey

spartey@inbar.int; stpartey@gmail.com

1 International Network for Bamboo and Rattan, Fumesua, Kumasi, Ghana

2 International Crops Research Institute for the Semi-Arid Tropics (ICRISAT), BP 320, Bamako, Mali

3 School of Environmental Sciences, University of Guelph, Guelph, ON N1G 2W1, Canada issues, declining soil fertility, poor markets, inadequate funding and poor infrastructural development [25, 63]. Moreover, these challenges are expected to be further exacerbated by climate change which has emerged as one of the major threats to development in Africa and its agriculture sector [15, 38]. Furthermore, SSA's quest to meet the SDGs will equally be challenged in years to come as its growing human population will inevitably lead to catastrophic consequences particularly in relation to ecosystem degradation, declining agricultural productivity and changing environment $[68,74]$. In order to sustainably develop in the future, it is essential to find solutions to these problems, particularly with regard to ensuring food security and coping with the changing environment [8]. Recent advances in global agricultural research have been focusing on the questions of increasing the resilience (against drought, erosion, fertility loss, etc.) and productivity of agricultural systems, which are directly related to increasing the adaptive capacity of farmers. The concept of climate-smart agriculture (CSA) dwells on this development agenda and aims at fostering the development and implementation of agriculture innovations that (1) sustainably increases agricultural productivity to support 
equitable increases in incomes, food security and development; (2) adapts and builds resilience to climate change from the farm to national levels; and (3) develops opportunities to reduce greenhouse gas emissions from agriculture compared with past trends [18, 31]. Research shows that agroforestry (a land-use system that combines trees/ shrubs and other perennials with crops and/or animals) can contribute substantially in this direction through its multiple benefits and ecosystem services. According to Verchot et al. [78], agroforestry provides a set of innovative practices that are designed to enhance productivity in a way that often contributes to climate change mitigation through enhanced carbon sequestration, and also strengthen the system's ability to cope with adverse impacts of changing climate conditions [11, 20, 34]. In addition, agroforestry options may provide a means for diversifying production systems and increasing the 'sustainagility' (allowing farmer's agility to continue) of smallholder farming systems [20].

In SSA, bamboo resources constitute one of the largest non-timber forests products identified to be a suitable complement to timber usages such as building and construction, pulpwood, flooring, panel products and furniture [48, 62]. In comparison with forest timber species, bamboo has a short gestation period of five years and has huge range of socioeconomic and environmental benefits [37]. In many parts of SSA, bamboo is currently being promoted for forest plantation developments to reduce the natural forests for timber and wood fuels [33, 52, 83]. However, scientists will agree that sole bamboo plantation developments may impact negatively on food security except they are arguably established on degraded lands. This makes the integration of bamboo into indigenous cropping systems (via agroforestry) agronomically interesting and necessary to meet both socioeconomic and environmental needs. While experiences from Asia and other countries demonstrate that the integration of bamboo within agricultural systems is a suitable approach for increased productivity of food crops and non-food biomass $[55,56]$, there are limited available data to verify the suitability of the technology in SSA (and Africa in general) and elucidate the ecological principles by which the system works. In addition, the current state of knowledge on bamboo agroforestry offers very little guidance as to how investments into the land-use system may contribute to sustainable rural development in SSA. Here, we reviewed the potential socioeconomic and environmental benefits of bamboo agroforestry and accentuate implications on sustainable development in SSA. In addition, we analysed potential research areas that could be intensified, so that future developments and scaling-up of bamboo agroforestry can be rooted in robust scientific findings rather than the intuitions of governments and development actors.

\section{Bamboo Resources and Utilization in SSA}

Bamboos are fast-growing woody grasses belonging to the grass family Gramineae and sub-family Bambusoideae [22]. Bamboos grow mostly in the tropics and subtropics in mixed forests or as pure stands and are cultivated in plantations, on homesteads and on farms [37] with a total area of covering 31.5 million hectares globally, thus accounting for about $0.8 \%$ of the world's total forest area in 2010 [21]. There are over 1500 bamboo species recorded worldwide, ranging in height from a few inches $(\mathrm{cm})$ to over $100 \mathrm{ft}(30 \mathrm{~m})$, with stem (culm) diameters of $1 / 8$ inch $(3 \mathrm{~mm})$ to over 10 inches $(25 \mathrm{~cm})$. In SSA, over 3 million hectares of bamboo forest was reported for seven countries (Ethiopia, Kenya, Ghana, Nigeria, Uganda, the United Republic of Tanzania and Zimbabwe) [45]. In Ethiopia, Nigeria and Ghana, bamboo covers about 6.5, 14 and 5\% their total forest vegetation, respectively [45, 59]. Common bamboo species in SSA include: Arundinaria alpine, Bambusa multiplex, B. vulgaris, B. bambos, B. pervariabilis, B. vulgaris var vitata (the yellow type), Oxythenanthera abyssinica, Dendrocalamus strictus and Oxytenanthera braunii. Although most bamboo resources grow naturally, greater attention has been paid in recent years to the establishment of planted bamboo. In most of SSA, planted bamboo is generally established to provide raw material and to avoid depletion of naturally regenerated stands. Some of the planted bamboos are introduced species from Asia. In Ghana, about 18 foreign bamboo species were introduced from Asia by the Forestry Commission. These include: Gigantochloa albociliata, Bambusa edulis, Dendrocalamus brandisii, B. oldhanmii, D. asper, Guadua angustifolia, D. strictus, G. chacoensis, D. membrenaceus, Thyrosostachis siamensis, D. latiflorus, $B$. textilis, B. ventricosa and B. burmanica [22]. In Kenya, over 20 bamboo species including: $B$. brandisii, $B$. vulgaris var. striata, B. arundinacea, B. tulda, D. membranaceus, $D$. strictus, D. brandisii, D. asper, O. abyssinica, Phyllostachys heterocycla var. pubescens and Thyrsostachys siamensis were introduced from Asia [61]. Several uses of bamboo are identified in SSA, but in contrast to exploitation and utilization of many timber species it remains one of the region's valuable underutilized resources [54]. Bamboo production is a major source of livelihood for several millions in SSA and remains an important part of small to medium enterprises that deals in crafts and charcoal production [16]. It is an important raw material for building construction $[48,62]$ and has been used as substrate for the African catfish, Clarias gariepinus [4], and the construction of bicycle frames [3] in Ghana. Bamboo leaves reportedly have antibiotic properties and are good medicine for curing fever [59]. Biomass productivity of 
bamboo varies based on ecologies, bamboo species, age and management. In most of SSA, the total dry matter production of a 4-year bamboo under optimum condition ranges from 80 to $120 \mathrm{Mg} \mathrm{ha}^{-1}$ year $^{-1}$ with a rotation cycle of 3-4 years [59].

\section{How Could SSA Benefit from Bamboo Agroforestry?}

The definition of agroforestry by Leakey [44] demonstrates a key feature of agroforestry as a land-use system that is designed to meet both environmental and socioeconomic needs for land users at all levels. However, the achievement of such socioeconomic and environmental benefits is normally dependent on the woody component which is the most integral of agroforestry systems. Below, we analyse certain socioeconomic and ecological needs in SSA which could be met through bamboo agroforestry.

\section{The Deforestation Menace and Increased Household Energy Needs}

Roughly 2.8 billion people worldwide including the world's poorest and most marginalized burn wood to satisfy their basic energy needs [7]. Historically, most rural households in SSA hugely depend on wood fuels to meet their household energy needs. Statistically, 81\% (about 653 million people) of SSA's population rely on traditional biomass fuels for cooking and heating which is even projected to increase to 720 million in 2030 [79]. Besides the conversion of forest lands into farmlands and bush fires, available literature points to fuelwood consumption as one major anthropogenic cause of deforestation in SSA [19]. In countries such as Ghana, rated among the top one per cent of West African countries with high consumption and demand for wood, the country is set to lose a gross revenue of US\$133.65 million equivalent to $2.6 \%$ of its 2008 agricultural sector Gross Domestic Product due to forest loss [14]. It is projected that increased degradation of forest resources due to fuelwood consumption and charcoal production could have catastrophic consequences on many national economies of SSA and forest fringe communities who derive their livelihoods from non-timber forest products [29, 35]. In addition, the limited electrification of many regions of SSA is expected to have serious demand implications on the region's wood fuel resource base, which is already threatened by the high deforestation rate [2]. The International Network for Bamboo and Rattan (INBAR) has demonstrated that using bamboo to make charcoal can take pressure off other forest resources and avoid deforestation. Bamboo's characteristics of fast growth and high renewability make it an efficient and renewable substitute resource for charcoal production. With a calorific value $\left(6959 \mathrm{cal} \mathrm{g}^{-1}\right)$ comparable to that of wood and almost half that of petroleum by weight, bamboo charcoal produces fewer pollutants than either and reportedly lasts longer [37]. In most countries in SSA, sustainable forest management has been made a priority, and government and scientists are now advocating the use of bamboo to reduce pressure on major commercial timber species sometimes sourced for household energy needs. With about $30 \%$ yield rate, SSA has a strong potential to produce about 9 million tons of bamboo charcoal on a sustainable basis which could potentially replace $64 \%$ of the region's wood consumption for charcoal production [59].

\section{Contribution to Climate Change Mitigation Through Carbon Sequestration}

Agricultural fields remain one of the major contributors to greenhouse gas emissions. Statistical information provided by Smith et al. [71] showed that agriculture accounted for an estimated emission of 5.1-6.1 $\mathrm{GtCO}_{2}$-eq year ${ }^{-1}$ in 2005 (10-12\% of total global anthropogenic emissions of greenhouse gases (GHGs)). With agricultural lands covering about half of the earth's land surface, reducing $\mathrm{CO}_{2}$ emissions could have huge implications on meeting targets set by the Intergovernmental Panel on Climate Change [78]. In comparison with monocultured crop lands, the incorporation of trees or shrubs into cropping systems (through agroforestry) is often recognized as a unique opportunity to mitigate climate change through carbon sequestration [51]. Agroforestry has been cited as a key land-use system in landscape-scale mitigation schemes under the REDD+ (Reduction Emissions from Deforestation and forest Degradation) and AFOLU (Agriculture, Forestry and Other Land Uses) concepts. Of all the land uses analysed in the Land-Use, Land-Use Change and Forestry report of the IPCC, agroforestry offered the highest potential for carbon sequestration in non-Annex I countries [78]. Considering the woody perennial (tree, shrub, palm and bamboo) is the integral component of an agroforestry system, most of the system's ability to sequester carbon is dependent on the woody perennial. Like most trees used in agroforestry, the integration of bamboo into cropping systems is one mainstream opportunity to mitigate climate change. Bamboo grows relatively fast and its high annual regrowth and renewability after harvesting may give bamboo agroforestry a high carbon storage potential especially when the harvested culms are transformed into durable products [73]. Measurements of carbon sequestration in bamboo agroforestry are limited, but estimates from bamboo plantations and forests are highly documented (particularly in Asia) and have been 
shown to vary depending on the type of plantation system, species composition, age of component species, geographic location, environmental factors and management practices. In a mixed patch of three village bamboo species ( $B$. cacharensis, B. vulgaris and B. balcooa) in the agroforestry system of north-east India, Nath and Das [55] found the carbon pool in the aboveground biomass ranged from 21.69 $\mathrm{Mg} \mathrm{ha}^{-1}$ during 2003 to $76.55 \mathrm{Mg} \mathrm{ha}^{-1}$ during 2006. Allocation of carbon was found to be more in culm components $(85-89 \%)$ than in branch $(8-10 \%)$ and leaf (3-4\%). The rate of aboveground $\mathrm{C}$ sequestration was 18.93-23.55 Mg ha ${ }^{-1} \mathrm{year}^{-1}$ with the mean of $21.36 \mathrm{Mg} \mathrm{ha}^{-1}$ year $^{-1}[55,56]$. In Japan, Song et al. [73] found that the total carbon stock of Phyllostachys bambusoides bamboo stands was $165.1 \mathrm{Mg} \mathrm{ha}^{-1}$, while that of Dendrocalamus strictus bamboo stands was $75.4 \mathrm{Mg} \mathrm{ha}^{-1}$. Reviews by Song et al. [73] and findings of Zhou and Jiang [85] found that the total carbon storage capacity in a typical bamboo ecosystem, including in the soil, was $106.36 \mathrm{Mg} \mathrm{ha}^{-1}$, of which the aboveground green vegetation stored $34.3 \mathrm{Mg} \mathrm{ha}^{-1}$, accounting for $32.3 \%$ of the total, and that the forest floor and soil (0-60 cm in depth) stored $72.2 \mathrm{Mg} \mathrm{ha}^{-1}$, accounting for $67.7 \%$ of the total. Further, a study conducted in Bangladesh found that the total carbon stock of a 5-year-old $B$. vulgaris was quite high (15.53 $\mathrm{Mg} \mathrm{ha}^{-1}$ year $^{-1}$ ) in comparison with some fast-growing tree species like Acacia auriculiformis (recording $10.21 \mathrm{Mg} \mathrm{ha}^{-1}$ year $^{-1}$ after 11 years) and $E u$ calyptus camaldulensis (recording $10.12 \mathrm{Mg} \mathrm{ha}^{-1}$ year $^{-1}$ after 18 years) recommended for the clean development mechanism (CDM) project [72]. This high annual rate of carbon accumulation means that bamboo agroforestry could be one of the most efficient land-use systems for carbon fixation. Additionally, the increased lifespan of durable bamboo products made through modern technology can ensure that the sequestered carbon will not return quickly to the atmosphere, thereby prolonging the carbon storage by bamboo [73]. Considering the large extent of degraded croplands and pasturelands in SSA and the potential to improve them using bamboo agroforestry, there is enormous potential to sequester additional carbon in such systems. In an agroforestry system with $50 \%$ of the plantation density or $30 \%$ of the plantation density, the system level $\mathrm{C}$ sequestration potentials are promising for SSA, along with annual and tuber crops.

\section{Sustainable Fodder Supply for Livestock}

In SSA, the livestock sector employs at least 100 million poor people including women [41, 58]. In the Sahelian zone, the sector accounts for about $35 \%$ of gross domestic product (GDP) and supplies about $30 \%$ of the revenue in the agriculture sector [75]. In addition, livestock provide draught power, skins, transport and manure and fulfil various sociocultural functions such as payment of dowry, establishment and reinforcement of relationships and source of prestige within the pastoral society [49, 84]. As a sector employing more than $60 \%$ of rural households in West Africa, investment in the livestock sector is critical in the quest to alleviate rural poverty and enhance food security. Among other factors, access to sustainable feed supply is one of the industry's key constraints. As most livestock are kept on a free-range system, forage of fair nutritive value is normally scarce in the dry season. During pasture scarcity periods, livestock are stall-fed on cereal crop residues and low-quality rangeland hay. These lowquality forage-based diets impede livestock productivity due to a lower dry matter (DM) intake, and lower digestibility and nutritive value of ingested feed. In most cases, livestock severely lose body weight, and the smallscale subsistence farmers often sell their animals at lower prices to avoid further production losses. The problem is further exacerbated by the inability of most farmers to provide supplementary feed sources [53], minerals and energy-rich feeds that optimizes microbial fermentation of low-quality fibrous feeds in the rumen that in turn increases total dry matter intake and improves animal productivity [27, 40, 65]. In this regard, tree leaves have received increasing attention, due to many advantages such as supply of good quality green fodder during the dry periods, and high crude protein and minerals contents [28, 39]. Considering this need, evergreen bamboo, which produces year-round litter production and has relatively high nutritive characteristics, may provide a valuable supplementary source of feed. In India, bamboo leaves are already used as fodder for ruminants, particularly when there is scarcity of pasture. In Himachal Pradesh and Uttarakhand during winter months, bamboo (Dendrocalamus hamiltonii) and dwarf bamboo leaves are extensively used as green fodder. All species of bamboos used as fodder have shown positive effects on cattle, particularly young calves, and reportedly increased milk production [76]. Furthermore, leaves of 27 species of bamboo analysed for their nutrient content were found to be rich in crude protein (9-19\%) and low in crude fibre $(18-34 \%)$ [70].

\section{Land Restoration and Soil Conservation}

Land degradation is a major biophysical problem in SSA normally contributed by the removal of vegetation through unstainable agricultural practices and illegal mining operations (Kusimi 2008; Kusimi 2015). Like most trees, bamboo has the propensity to improve soils as it grows on marginal soils with low fertility. In Brazil, bamboo species such as Bambusa blumeana and Phyllostachys pubescens are used in controlling soil erosion, preventing nutrient loss 
and improving soil structure [24]. The valuable features of bamboo for controlling soil erosion are its extensive fibrous root system, connected rhizome system, the leafy mulch it may produce on the soil surface, its comparatively dense foliage which protects against beating rains and its habit of producing new culms from underground rhizomes which allows harvesting without disturbing the soil [10]. In China, a 5-year field experiment conducted showed an average surface soil run-off per month in bamboo forests of only $0.10 \mathrm{~m}^{3} \mathrm{ha}^{-1}$, which is equivalent to only $77 \%$ of the rate for the Chinese fir forest and $35 \%$ of the rate for the Pinus massoniana forest [80]; the resulting sediment delivery rate was $0.18 \mathrm{~kg} \mathrm{ha}^{-1}$, amounting to only $42.8 \%$ of the rate for the Chinese fir forest and $23.6 \%$ for the $P$. massoniana forest [73]. In order to restore degraded agricultural lands in central India, Behari et al. [9] developed successful seven agroforestry models with three bamboos (B. bamboos, B. nutans and D. strictus). The inter crops were: soybean (Glycine max), moong (Phaseolus aureus), wheat (Triticum aestivum), urad (Phaseolus mungo), pigeon pea (Cajanus cajan) and mustard (Brassica campestris).

\section{Poverty Reduction and Food Security}

In SSA, bamboo-based agroforestry systems are now developing and available literature on their economic feasibilities is limited. However, with livelihoods in SSA mostly tied to agriculture and forestry, investments in bamboo-based agroforestry systems may contribute to rural poverty reduction and improved livelihoods in the region. Like most agroforestry systems, bamboo-based agroforestry systems are expected to open new income streams by diversifying agroecosystems and offering multiple economic benefits from the sale of grains and vegetables from short-duration crops (integrated with bamboo), supply of fodder for livestock and the sale of processed bamboo culms as wood fuels, charcoal, timber or industrial raw materials [51]. In most of SSA, it is common for rural households to diversify income streams as a pathway to reduce vulnerability to the failure of their primary incomegenerating activities [6, 17]. In addition to vulnerability reduction, market opportunities also influence many households to indulge in other activities that sustainably generate income within shorter periods [47]. For this reason, charcoal production during the dry seasons is common among farmers as a secondary income-generating activity. As regional and national environmental policies are likely to favour bamboo agroforestry in future as a major source of wood biomass for charcoal and firewood due to high rates of forest degradation, bamboo agroforestry will provide new vistas of income opportunities for charcoal producers. Income from charcoal sales will (1) provide safety nets in times of shortfalls in incomes derived from arable farming, livestock or fisheries; (2) support current charcoal/wood fuel consumption; and (3) serve as a potential pathway out of poverty $[1,82]$. With a projected rise in the consumption of wood fuels and charcoal by 2030, economic returns from bamboo-processed wood fuels and charcoals are also expected to rise. Bamboo is already contributing to household income security in SSA. In Ethiopia, a survey of 345 households showed bamboo income contributed up to $11 \%$ of the annual cash income of households [52] which shows investment in bamboo production could be a poverty reduction strategy for many SSA countries. While bamboo agroforestry could be economically prosperous, households will have to meet the financial and social capital requirements to engage in the production and marketing of potential saleable products [81].

Besides contributions to household income, bamboo agroforestry could also contribute to the food security and nutritional needs of SSA. The shoots of bamboo have good profile of minerals and nutrients such as protein, fibre, sugar, amino acids and inorganic salts. Table 1 shows the nutrient components of some bamboo species in SSA compared with some of the common vegetables widely grown and eaten in SSA. In many parts of Asia, Europe, Australia and the USA, bamboo shoots are widely eaten as important part of meals. In SSA, there are many bamboo species that produce edible shoots. However, they are not known to many due to limited awareness. With increased purchasing cost of many high value vegetables in SSA, bamboo shoots could be a viable cost-effective source of protein, vitamin and mineral for many households.

\section{In Which Agroforestry System Could Bamboo be Used?}

Several agroforestry systems in SSA are characterized and their designs are matched to ecologies and farmers' needs in this section. In addition, the design of an agroforestry system may be dependent on the associated non-woody component (crop or livestock) as well as the morphological and physiological characteristics of the woody perennial. In the case of bamboo, sympodial and monopodial forms may have different agroforestry recommendations. In sympodial bamboos, new culms develop from buds on elongated culm necks (pseudorhizomes) rather than from buds on rhizomes. Generally, monopodial bamboos are native to temperate climates with cool, wet winters and sympodial bamboos to tropical climates with a pronounced dry season $[55,57]$. In SSA, most of the available bamboo species are sympodial and are highly concentrated in the forest agroecological zones. Such bamboo species may be suitable for boundary planting, windbreak and shelterbelt 


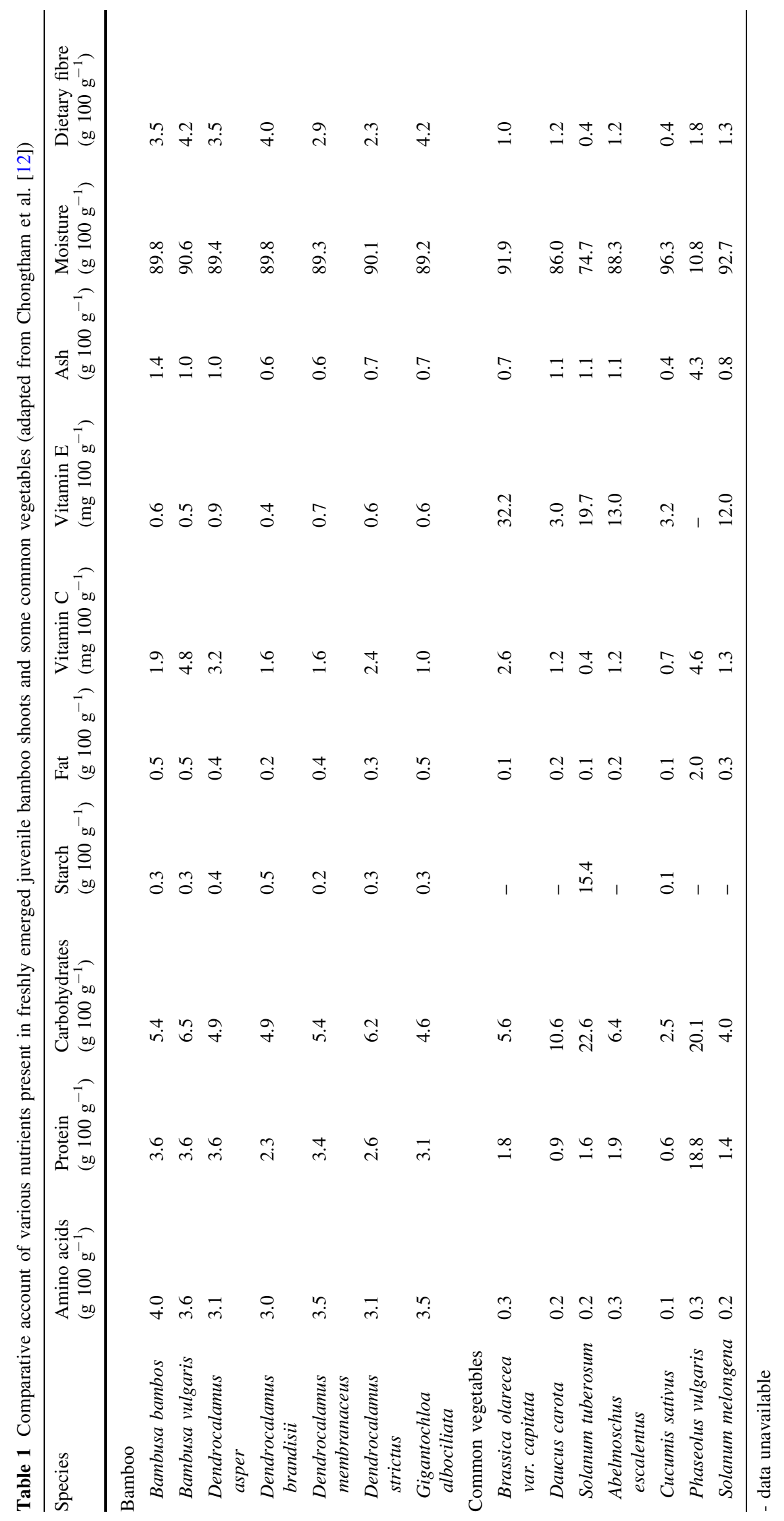


systems or as planted fallows on degraded lands. Similar agroforestry systems with sympodial bamboo species have been successfully developed in India [32]. The development of any of the aforementioned agroforestry systems with bamboo species such as $B$. multiplex, $B$. vulgaris (the green type), B. bambos, B. pervariabilis, B. vulgaris var vitata, $O$. abyssinica or $D$. strictus could be an opportunity to develop a sustainable bamboo biomass resource base for firewood and charcoal. In addition, boundary planting and windbreak systems with bamboo could reduce risks of crop failure and demarcate farm boundaries to minimize land litigations. Considering natural stands of bamboos (e.g. $B$. vulgaris) are found around water bodies in SSA, this could be a unique opportunity to manage them for riparian buffer agroforestry developments around major water bodies. Riparian buffers are important for water resource conservation and serve other ecosystem services (such as provision of habitat for wildlife) [26, 69]. Including the aforementioned systems, monopodial bamboos may be most suitable for intercropping systems. In such intercropping systems, bamboo can be planted at varied spacing of $4 \mathrm{~m} \times 4 \mathrm{~m}$ to $8 \mathrm{~m} \times 8 \mathrm{~m}$, depending on the clump size of the species. In India, crops such as finger millet, cowpea, bottle gourd, turmeric, sesame and sweet potato were found to be more suitable [32]. Bamboo intercropping systems are rare in SSA with the latest being an INBAR-led bamboo agroforestry pilot project in the dry semi-deciduous zone of Ghana where different cropping systems with maize, cowpea and cassava are planted between the rows of B. balcooa and $O$. abyssinica in the quest to develop a model bamboo-based agroforestry system. While shading effects beyond three years of bamboo establishment may restrict crop integration, other shade-tolerant crops like ginger could still form part of such an integrated land-use system. Furthermore, with relatively high nutritional composition of bamboo leaves, bamboo silvopasture systems could be developed and scaled up in SSA particularly in the Savannah/Sahel areas where livestock production is a major livelihood activity. This implies that even at stages where major food crops could not be integrated with bamboo due to canopy closure, bamboo fodder could supplement the nutrient requirements of livestock particularly during the dry seasons where fodder of optimum nutritional quality is often scarce.

\section{What Can Constrain Bamboo Agroforestry Adoption in SSA?}

Although agroforestry is often viewed as a sound land-use system well adapted to the social and ecological environment of SSA [64], large-scale landscape adoption of agroforestry is relatively low. Referring from the reviews by Franzel [23] and Place and Dewees [66], several factors are likely to influence adoption of bamboo agroforestry innovations: (1) biophysical adaptation of the innovationthe ability of the innovation to adapt and be adapted successfully to the farm environment; (2) profitability of the innovation-in a broad sense to include consideration of returns to labour and land as well as financial profitability; (3) farmers' awareness of the innovation; (4) access to land, labour and water; (5) access to social capital, particularly where group action is needed; (6) availability of essential inputs, particularly seed; (7) access to financial capital; and (8) degree of risk and uncertainty. Like most agroforestry systems, bamboo-based agroforestry systems are also likely to be faced with (9) the lack of effective and efficient land tenure systems that provide a long-term guarantee of benefit from upfront investments [42, 43].

\section{Research Needs for Bamboo Agroforestry Development in SSA}

Giving bamboo agroforestry is relatively new in SSA, it is imperative that research on the socioeconomic and biophysical aspects of it is intensified, so that future developments and scaling-up can be rooted in robust scientific findings rather than the intuitions of governments and development actors. In Sects. 6.1-6.3, we highlight some relevant areas of research for bamboo agroforestry development in SSA.

\section{Ethnobotany and Socioeconomic Aspects of Bamboo Agroforestry}

The woody perennial of an agroforestry system technically defines its socioeconomic importance. It is therefore imperative that one assesses the local knowledge of bamboo within the intended agroecological zone of establishment. Assessment of local knowledge of bamboo may involve determining local bamboo use, ecological distribution as well as taboos and belief systems about its cultivation and utilization. Local knowledge of bamboo may reveal new vistas of bamboo use as well as constraints that may restrict its adoption by farmers. A major methodology to achieving this is the administration of questionnaire interviews and field observations that emphasize on the aforementioned areas and offers the platform to clear doubts and enigma through knowledge sharing. Considering the dynamic and changing nature of agricultural practices in SSA, understanding the factors that drive changes within the intended locality may also help guide strategies to promote sustainable bamboo agroforestry. The drivers of changes could be natural or human-induced factors that directly or indirectly bring about changes in any 
Table 2 Possible tree-soil-crop interaction processes in tropical bamboo agroforestry systems (adapted from Rao et al. [67])

\begin{tabular}{|c|c|}
\hline Nature of interaction & Process \\
\hline \multicolumn{2}{|l|}{ Soil fertility: chemical } \\
\hline Carbon & $\begin{array}{l}\text { Increases in active pools of soil organic matter through litterfall, root turnover and incorporation of tree prunings and } \\
\text { crop residues }\end{array}$ \\
\hline Nitrogen & Increased soil $\mathrm{N}$ supply through deep soil $\mathrm{N}$ capture and reduced leaching \\
\hline Phosphorus & Transformation of less available inorganic $\mathrm{P}$ forms into readily plant-available forms \\
\hline Cations $(\mathrm{Ca}, \mathrm{Mg}, \mathrm{K})$ & Relocation in soil profile, organic acids binding $\mathrm{Al}$, localized $\mathrm{Al}$ detoxification \\
\hline $\begin{array}{l}\text { Soil fertility: } \\
\text { physical }\end{array}$ & $\begin{array}{l}\text { Improved soil aggregation, porosity and pore connectivity, reduced bulk density, break up of hardpans/compacted soil } \\
\text { layers }\end{array}$ \\
\hline $\begin{array}{l}\text { Soil fertility: } \\
\text { biological }\end{array}$ & Build-up of soil macrofauna and microbial populations, reduced/increased soil insect pests and pathogens \\
\hline Competition & Sharing of growth resources: light, water and nutrients by trees and crops \\
\hline Microclimate & Shading (reduced soil and air temperature), shelter (protection from wind), rainfall interception and redistribution \\
\hline Conservation & Reduced soil erosion, reduced leaching \\
\hline \multicolumn{2}{|l|}{ Biological } \\
\hline Weeds & $\begin{array}{l}\text { Reduced weed population, shifts in weed species, decreased viability of perennial weed rhizomes, decay of annual weed } \\
\text { seed bank }\end{array}$ \\
\hline Pests and diseases & Reduced/increased pest-parasite/predator populations \\
\hline Allelopathy & Release of growth-affecting chemicals into soil environment \\
\hline
\end{tabular}

agricultural production systems [30]. As these factors are more related to needs and profitability, it will be crucial to investigate the advantages bamboo could potentially contribute to meeting the subsistent and/or commercial needs of farmers. Further, the competitive advantage of bamboo (in terms of costs and benefits) would have to be assessed and compared with trees or shrubs that offer comparable use and importance.

\section{Ecological Processes and Component Interaction Within Bamboo Agroforestry}

According to Ong et al. [60], the success of any agroforestry system is dependent on the interaction between the woody perennial and associated components. Such interactions may occur aboveground or belowground. Competitive and complementary interaction within a bamboo agroforestry system may be dependent on the arrangement of the components, planting density and the level of technical management [5, 77]. The study of interactions in bamboo agroforestry may require the examination of complex ecological processes. Table 2 provides a summary of typical tree-soil-crop interaction processes that could be expected within a tropical bamboo agroforestry system. Experimental designs with different planting spacing and density of bamboo and crops may be crucial in defining the best cultural practices applicable to specific bamboo species and agricultural crops. In addition, quantifying the spatio-temporal scales of the processes enumerated in Table 2 would inform management decisions and investment options that promote the productivity and sustainability of bamboo agroforestry [36].

\section{Testing Bamboo Fodder for a Wide Range of Livestock}

In the quest to develop bamboo-based silvopasture systems, it will be imperative to (1) determine integrated tree/ crop-livestock production systems in an intended locality; (2) identify predominant livestock feeding practices; (3) document priority fodder species and assess farmers' ethnobotanical knowledge about the species; (4) determine the nutritional and mineral profile of the prioritized livestock feed sources; (5) assess the consumption patterns and digestibility of prioritized fodder species in comparison with bamboo; and (6) evaluate the growth and health (using haematological indicators and serum biochemistry) of livestock fed with fodder from common species in comparison with bamboo. In SSA, bamboo generally grows throughout the country although mostly concentrated in the forest agroecologies. The development of bamboo-based silvopasture systems will be a unique opportunity for farmers in the Savannah/Sahel agroecological zones where livestock production is a major livelihood activity.

\section{Conclusions}

The Food and Agriculture Organization (FAO) recently recommended the adoption of agroforestry practices (treebased farming practices) for food security in all Sub- 
Saharan African (SSA) countries, and the need of SSA country governments to incorporate agroforestry into their national agricultural policies. Presently, agroforestry innovations are encouraged as a sustainable approach to food security in the UN Sustainable Development Goals. The socioeconomic and ecological importance of bamboo is not farfetched particularly with the provision of huge biomass source for renewable energy, potential for restoring degraded forestlands and also as a sustainable carbon sink. By incorporating bamboo into mixed-use agroforestry complexes, we can maximize its functionality while integrating it with other production crops. As a relatively new innovation, it is imperative that research on the socioeconomic and biophysical aspects of it is intensified, so that future developments and scaling-up can be rooted in robust scientific findings rather than the intuitions of governments and development actors.

Acknowledgement This review paper was produced as an activity of BiomassWeb (grant no. 031A258A), a project funded by the German Federal Ministry of Education and Research (BMBF) in the context of the initiative GlobE "Securing the Global Food Supply". BiomassWeb is managed by the Center for Development Research, Universität of Bonn, Germany. The authors also thank the two anonymous reviewers and the handling editor for their immense contributions to improving the content of this paper.

\section{References}

1. Adam YO, Eltayeb AM (2016) Forestry decentralization and poverty alleviation: a review. In press, For Policy Econ. doi: 10.1016/j.forpol.2016.05.009

2. Adkins E, Oppelstrup K, Modi V (2012) Rural household energy consumption in the millennium villages in Sub-Saharan Africa. Energy Sustain Dev 16:249-259

3. Agyekum EO, Fortuin KPJ, van der Harst EJM (2014) Comparative life cycle assessment of ghana-made bamboo-frame bicycle and conventional bicycles assembled and used in the Netherlands. In: Proceedings of the 2014 [avniR] conference

4. Amisah S, Adjei-Boateng D, Afianu DD (2008) Effects of bamboo substrate and supplementary feed on growth and production of the African catfish, Clarias gariepinus. J Appl Sci Environ Manag 12:25-28

5. Atangana AR, Khasa PD, Chang S, Degrande A (2014a) Ecological interactions and productivity in agroforestry systems. In: Atangana AR, Khasa PD, Chang S, Degrande A (eds) Tropical agroforestry. Springer, New York, pp 151-172

6. Babulo B, Muys B, Nega F, Tollens E, Nyssen J, Deckers J, Mathijs E (2008) Household livelihood strategies and forest dependence in the highlands of Tigray, Northern Ethiopia. Agr Syst 98:147-155

7. Bailis R, Drigo R, Ghilardi A, Masera O (2015) The carbon footprint of traditional wood fuels. Nat Clim Change 5:266-272

8. Batish DR, Kohli RK, Jose S, Singh HP (eds) (2008) Ecological basis of agroforestry. CRC Press, Taylor and Francis Group, Boca Raton, FL

9. Behari B, Agarwal R, Singh AK, Banerjee SK (2004) Spatial variability of $\mathrm{pH}$ and organic carbon in soils under bamboo based agroforestry models in a degraded area. Indian For 130:521-529
10. Ben-Zhi Z, Mao-Yi F, Jin-Zhong X, Xiao-Sheng Y, Zheng-Cai L (2005) Ecological functions of bamboo forest: research and application. J Forest Res 16:143-147

11. Borland AM, Wullschleger SD, Weston DJ, Hartwell J, Tuskan GA, Yang X, Cushman JC (2015) Climate-resilient agroforestry: physiological responses to climate change and engineering of crassulacean acid metabolism (CAM) as a mitigation strategy. Plant Cell Environ 38:1833-1849

12. Chongtham N, Bisht MS, Haorongbam S (2011) Nutritional properties of bamboo shoots: potential and prospects for utilization as a health food. Compr Rev Food Sci Food 10:153-168

13. Costanza R, Fioramonti L, Kubiszewski I (2016) The UN sustainable development goals and the dynamics of well-being. Front Ecol Environ 14:59

14. Damnyag L, Tyynelä T, Appiah M, Saastamoinen O, Pappinen A (2011) Economic cost of deforestation in semi-deciduous forests-a case of two forest districts in Ghana. Ecol Econ 70:2503-2510

15. Dumenu WK, Obeng EA (2016) Climate change and rural communities in Ghana: social vulnerability, impacts, adaptations and policy implications. Environ Sci Policy 55:208-217

16. Effah B, Boampong E, Asibey O, Pongo NA, Nkrumah A (2014) Small and medium bamboo and rattan enterprises in economic empowerment in Kumasi: perspectives of producers. J Soc Econ $1: 11-21$

17. Ellis F, Kutengule M, Nyasulu A (2003) Livelihoods and rural poverty reduction in Malawi. World Dev 3:1495-1510

18. FAO (2010) Climate smart agriculture: policies, practices and financing for food security, adaptation and mitigation. Food and agriculture organization, Rome

19. FAO (2010) Global forest resources assessment 2010. Food and Agriculture Organization of the United Nations, Rome

20. FAO (2013) Advancing agroforestry on the policy agenda: a guide for decision-makers. In: Buttoud G. in collaboration with Ajayi O, Detlefsen G, Place F, Torquebiau E (eds) Agroforestry Working Paper No. 1. Food and Agriculture Organization of the United Nations. FAO, Rome

21. FAO, JRC (2012) Global forest land-use change 1990-2005. In: Lindquist EJ, D’Annunzio R, Gerrand A, MacDicken K, Achard F, Beuchle R, Brink A, Eva HD, Mayaux P, San-Miguel-Ayanz J, Stibig HJ (eds) FAO Forestry Paper No. 169. Food and Agriculture Organization of the United Nations and European Commission Joint Research Centre. FAO, Rome

22. Forestry Commission (2016) Bamboo Resources. http://www.fcghana.org/baradep/ page.php?page $=139 \&$ section $=29 \&$ typ $=1$. Accessed 13 April 2016

23. Franzel S (1999) Socioeconomic factors affecting the adoption potential of improved tree fallows in Africa. Agroforest Syst 47:305-321

24. Fu M, Xiao J, Lou Y (2000) Cultivation and utilization on bamboo $[\mathrm{M}]$. China Forestry Publishing House, Beijing

25. Goldstein M, Udry C (2008) The profits of power: land rights and agricultural investment in Ghana. J Polit Econ 116:981-1022

26. Gray CL, Simmons BI, Fayle TM, Mann DJ, Slade EM (2016) Are riparian forest reserves sources of invertebrate biodiversity spillover and associated ecosystem functions in oil palm landscapes? Biol Conserv 194:176-183

27. Habib G, Khan NA, Sultan A, Ali M (2016) Nutritive value of common tree leaves for livestock in the semi-arid and arid rangelands of Northern Pakistan. Livest Sci 184:64-70

28. Habib G, Saleem M, Hameed A (2013) Mineral composition of local tree leaves for feeding sheep and goats in Kohat district of Khyber Pakhtunkhwa. Sarhad J Agric 29:97-103

29. Hansen CP, Pouliot M, Marfo E, Obiri BD, Treue T (2015) Forests, timber and rural livelihoods: implications for social 
safeguards in the Ghana-EU voluntary partnership agreement. Small Scale For 14(4):401-422

30. Hazell P, Wood S (2008) Drivers of change in global agriculture. Philos Trans Royal Soc Lond B Biol Sci 363:495-515

31. Hengsdijk H, Conijn JG, Verhagen A (2015) Climate smart agriculture: synthesis of case studies in Ghana, Kenya and Zimbabwe, Report 624. Foundation Stichting Dienst Landbouwkundig Onderzoek (DLO) research institute, Plant Research International, Wageningen, UR, p 26

32. Hiwale S (2015) Sustainable horticulture in semiarid dry lands. Springer, India

33. Hoogendoorn JC, Benton A (2014) 13 Bamboo and rattan production and the implications of globalization. Forests and Globalization: challenges and opportunities for sustainable development.

http://www.environmentportal.in/files/file/bamboo_1.pdf

34. Hunde KK (2015) The role of agroforestry system as strategy to adapt and mitigate climate change: a review with examples from tropical and temperate regions. Clim Change 1:20-25

35. Husseini R, Kendie SB, Agbesinyale P (2015) Community participation in the management of forest reserves in the Northern Region of Ghana. Int J Sustain Dev World 20:1-2

36. Imo M (2009) Interactions amongst trees and crops in taungya systems of western Kenya. Agrofor Syst 76:265-273

37. INBAR (2014) Bamboo: a strategic resource for countries to reduce the effects of climate change. International Network for Bamboo and Rattan, Beijing

38. Jalloh A, Nelson GC, Thomas TS, Zougmoré R, Roy-Macauley H (eds) (2013) West African agriculture and climate change. International Food Policy Research Institute, Washington

39. Khan NA, Habib G (2012) Assessment of Grewia Oppositifolia leaves as feed supplement: nutrient composition, protein degradability, $\mathrm{N}$ metabolism and growth rate in sheep. Trop Anim Health Prod 44:1375-1381

40. Khan NA, Habib G, Ullah G (2009) Chemical composition, rumen degradability, protein utilization and lactation response to selected tree leaves as substitute of cottonseed cake in the diet of dairy goats. Anim Feed Sci Technol 154:160-168

41. Kristjanson P, Waters-Bayer A, Johnson N, Tipilda A, Njuki J, Baltenweck I, Grace D, MacMillan S (2014) Livestock and women's livelihoods. In: Quisumbing AR, Meinzen-Dick R, Raney TL, Croppenstedt A, Behrman JA, Peterman A (eds) Gender in agriculture. Springer, pp 209-233. http://libcatalog.cimmyt.org/download/general/ 98958.pdf\#page $=220$. Accessed 13 March 2016

42. Kusimi JM (2008) Assessing land use and land cover change in the Wassa West District of Ghana using remote sensing. GeoJournal 71:249-259

43. Kusimi JM (2015) Characterizing land disturbance in Atewa range forest reserve and buffer zone. Land Use Policy 49:471-482

44. Leakey RRB (1996) Definition of agroforestry revisited. Agrofor Today 8(1):5-7

45. Lobovikov M, Paudel S, Piazza M, Ren H, Wu J (2007) World bamboo resource: a thematic study prepared in the framework of the Global Forest Resources Assessment 2005. Food and Agriculture Organization of the United Nation, Rome

46. Lofgren H, Richards A, El Mesbahi KM (2015) Food security poverty and economic policy in the Middle East and North Africa. Bull Ã conomique et Social du Maroc 159:1-31

47. Man N, Sadiya SI (2009) Off-farm employment participation among paddy farmers in the MUDA Agricultural Development Authority and Kemasin Semerak Granary areas of Malaysia. Asia Pac Dev J 16:141-153
48. Mark AA, Russell AO (2011) A comparative study of Bamboo reinforced concrete beams using different stirrup materials for rural construction. Int J Civil Struct Eng 2:407

49. Martin R, Linstädter A, Frank K, Müller B (2016) Livelihood security in face of drought-assessing the vulnerability of pastoral households. Environ Modell Softw 75:414-423

50. Masters WA, Djurfeldt AA, De Haan C, Hazell P, Jayne T, Jirström M, Reardon T (2013) Urbanization and farm size in Asia and Africa: implications for food security and agricultural research. Global Food Secur 2:156-165

51. Mbow C, Van Noordwijk M, Luedeling E, Neufeldt H, Minang PA, Kowero G (2014) Agroforestry solutions to address food security and climate change challenges in Africa. Curr Opin Environ Sustain 6:61-67

52. Mekonnen Z, Worku A, Yohannes T, Alebachew M, Kassa H (2014) Bamboo Resources in Ethiopia: their value chain and contribution to livelihoods. Ethnobot Res Appl 12:511-524

53. MOFA (2013) Agriculture in Ghana: facts and Figures. Ministry of Food and Agriculture, Statistics, Research and Information Directorate. Accra. http://mofa.gov.gh/site/?page_id=6032. Accessed 13 May 2016

54. Musau Z (2016) Bamboo: Africa's untapped potential. http://www.un.org/africarenewal/magazine/april-2016/bambooafrica\%E2\%80\%99s-untapped-potential Accessed 1 June 2016

55. Nath AJ, Das AK (2012) Carbon pool and sequestration potential of village bamboos in the agroforestry system of northeast India. Trop Ecol 53:287-293

56. Nath AJ, Lal R, Das AK (2015) Ethnopedology and soil quality of bamboo (Bambusa sp.) based agroforestry system. Sci Total Environ 521:372-379

57. Nath S, Das R, Chandra R, Sinha A (2009) Bamboo based agroforestry for marginal lands with special reference to productivity, market trend and economy. Agroforestry in Jharkhand, Envis Jharkhand News, pp 80-96

58. Nyberg G, Knutsson P, Ostwald M, Öborn I, Wredle E, Otieno DJ, Mureithi S, Mwangi P, Said MY, Jirström M, Grönvall A (2015) Enclosures in West Pokot, Kenya: transforming land, livestock and livelihoods in drylands. Pastoralism 5(1):1-12

59. Obiri BD, Oteng-Amoako AA (2007) Towards a sustainable development of the bamboo industry in Ghana. Ghana J For 21:14-27

60. Ong CK, Black C, Wilson J (eds) (2015) Tree-crop Interactions: agroforestry in a changing climate. CABI, Wallingford, UK

61. Langat D, Ongugo P, Musila W (2012) Ecological and socioeconomic study on bamboo farming in the western Mt. Kenya region. Kenya forestry research institute and National museum of Kenya, Nairobi, Kenya.

62. Opoku D, Ayarkwa J, Agyekum K (2016) Factors Inhibiting the use of bamboo in building construction in Ghana: perceptions of construction professionals. Mater Sci Appl 7(02):83

63. Partey ST (2011) Effect of pruning frequency and pruning height on the biomass production of Tithonia diversifolia (Hemsl) A. Gray. Agrofor Syst 83:181-187

64. Partey ST, Thevathasan NV (2013) Agronomic potentials of rarely used agroforestry species for smallholder agriculture in Sub-Saharan Africa: an exploratory study. Commun Soil Sci Plan 44:1733-1748

65. Patra AK (2010) Effects of supplementing low-quality roughages with tree foliages on digestibility, nitrogen utilization and rumen characteristics in sheep: a meta-analysis. J Anim Physiol Anim Nutr 94:338-353

66. Place F, Dewees P (1999) Policies and incentives for the adoption of improved fallows. Agrofor Syst 47:323-343

67. Rao MR, Nair PK, Ong CK (1998) Biophysical interactions in tropical agroforestry systems. In: Nair PKR, Latt CR (eds) 
Directions in tropical agroforestry research. Springer Netherlands, pp 3-50

68. Ruf F, Schroth G, Doffangui K (2015) Climate change, cocoa migrations and deforestation in West Africa: what does the past tell us about the future? Sustain Sci 10:101-111

69. Şekercioğlu ÇH, Loarie SR, Oviedo-Brenes F, Mendenhall CD, Daily GC, Ehrlich PR (2015) Tropical countryside riparian corridors provide critical habitat and connectivity for seed-dispersing forest birds in a fragmented landscape. J Ornithol 156:343-353

70. Singhal P, Satya S, Sudhakar P (2011) Antioxidant and pharmaceutical potential of bamboo leaves. Bamboo Sci Cult 24:19-28

71. Smith P, Martino D, Cai Z, Gwary D, Janzen H, Kumar P, McCarl B, Ogle S, O’Mara F, Rice C, Scholes B (2007) Policy and technological constraints to implementation of greenhouse gas mitigation options in agriculture. Agri Ecosyst Environ 118:6-28

72. Sohel MS, Alamgir M, Akhter S, Rahman M (2015) Carbon storage in a bamboo (Bambusa vulgaris) plantation in the degraded tropical forests: implications for policy development. Land Use Policy 49:142-151

73. Song X, Zhou G, Jiang H, Yu S, Fu J, Li W, Wang W, Ma Z, Peng C (2011) Carbon sequestration by Chinese bamboo forests and their ecological benefits: assessment of potential, problems, and future challenges. Environ Rev 19:418-428

74. Stow DA, Weeks JR, Shih HC, Coulter LL, Johnson H, Tsai YH, Kerr A, Benza M, Mensah F (2016) Inter-regional pattern of urbanization in southern Ghana in the first decade of the new millennium. Appl Geogra 71:32-43

75. SWAC-OECD/ECOWAS (2008) Livestock and regional market in the Sahel and West Africa-potentials and challenges. Sahel and West Africa Club/OECD, Paris, p 151
76. Thapa B, Walker DH, Sinclair FL (1997) Indigenous knowledge of the feeding value of tree fodder. Anim Feed Sci Technol 68:37-54

77. Thevathasan NV, Gordon AM (2004) Ecology of tree intercropping systems in the North temperate region: experiences from southern Ontario, Canada. Agrofor Syst 61:257-268

78. Verchot LV, Van Noordwijk M, Kandji S, Tomich T, Ong C, Albrecht A, Mackensen J, Bantilan C, Anupama KV, Palm C (2007) Climate change: linking adaptation and mitigation through agroforestry. Mitig Adapt Strateg GL 12:901-918

79. Wicke B, Smeets E, Watson H, Faaij A (2011) The current bioenergy production potential of semi-arid and arid regions in sub-Saharan Africa. Biomass Bioenerg 35:2773-2786

80. Wu ZN, Fu J, Zhuang JY (2003) Study on hydrological and soil conservation benefit of Moso bamboo forest and other forests. J Anhui Agric Sci 31:200-202

81. Wunder S (2001) Poverty alleviation and tropical forests-what scope for synergies? World Dev 29:1817-1833

82. Wunder S, Bourner J, Shively G, Wyman M (2014) Safety nets, gap filling and forests: a global-comparative perspective. World Dev 64:S29-S42

83. Xuhe C (2003) Promotion of bamboo for poverty alleviation and economic development. J Bamboo Rattan 2:345-350

84. Zaibet L, Traore S, Ayantunde A, Marshall K, Johnson N, Siegmund-Schultze M (2011) Livelihood strategies in endemic livestock production systems in sub-humid zone of West Africa: trends, trade-offs and implications. Environ Dev Sustain 13(1):87-105

85. Zhou GM, Jiang PK (2004) Density, storage and spatial distribution of carbon in Phyllostachys pubescens forest. Sci Silv Sin 40:20-25 